\title{
The effects of information content of cash flow statement, dividend payout ratio, economic value added and corporate social responsibility on stock trading volume
}

\author{
Dwi Luvira Oktavianingsi, ${ }^{1}$ Otniel Safkaur, ${ }^{2}$ \\ Pascalina V.S. Sesa ${ }^{3}$ \\ 1,2,3Universitas Cenderawasih Jayapura, Indonesia \\ email: dwiluvira53@gmail.com
}

\begin{abstract}
Purpose - This study aims to empirically test and analyze the influence of information content of cash flow statements, Dividend Payout Ratio (DPR), Economic Value Added (EVA) Corporate Social Responsibility (CSR) on the trading volume of empirical study stocks in manufacturing companies listed on the Indonesia Stock Exchange from 2014 to 2018.

Method - The number of samples used in this study was 169 taken from financial report on idx. The analytical techniques used were multiple regressions in order to obtain a comprehensive picture of the relationship between variable and each other. This research used a quantitative approach with its research population of companies included in the manufacturing sector listed on the Indonesia Stock Exchange in 20142018.

Result - Based on the results of this study, investment cash flow and Dividend Payout Ratio (DPR) significantly influenced the trading volume of stocks. Meanwhile, operating cash flow, funding cash flow, Economic Value Added (EVA) and Corporate Social Responsibility (CSR) had no significant effect on stock trading volume.

Implication - This research is suggested to improve development of trading volume in investor decision making for investment and for companys' performance assessment.

Originality - This research is the study that used content of cash flow resporting information, dividend payout ratio, economic value added, corporate social responsibility on stock trading volume.
\end{abstract}

Keywords: content of cash flow; dividend payout ratio; economic value added; csr 


\section{Introduction}

With the rapid development of the capital market, the publication of relevant information in investors making decisions is also increasing, JIAFR | 54 especially in recent years. Activities in the capital market are always attached to the availability of various information about the company. Very basic information needed by investors during the process of decision-making is the performance of the company. One of the performances of companies that have gone global or go public in the capital market can be the volume of stock trading. Stock trading volume is one indication to assess the movement of the capital market. If the announcement of information provided by the company shows signs of good signals for investors, then the stock trading volume will rise (Azhar et al., 2009).

Many factors can influence the high or low trading volume of stocks, namely the valuation of the company's performance, economic conditions, income level, government policy, supply and demand, rate of inflation, and share price (Ayuningrum, 2015). What is expected by investors is a belief that investors get reasonable, clear, precise information and the level of return that will be obtained on the investment in the decision-making to be willing to deposit fund through the capital market.

In these circumstances, financial statement published as a final result of an accounting process is a very important source of information for prospective creditors, investors, external users, and interested parties with issuers, because financial statements have the main objective of making decisions for investment and other decisions (Sutriasih et al., 2013). The financial statements required by investors in relation to decision-making are income statements and cash flow.

In investing shares in a company in the capital market, investors have the aim of improving their welfare and want a reward or profit in the form of dividends. According to Sutriasih et al. (2013), if the profit that can be generated by a large issuer company, then the dividend distributed is also large, whereas if the profit that can be generated by a small company then the 
The effects of information content of cash flow statement, dividend payout ratio ...

dividend distributed is relatively small. Investors who are encouraged or interested in investing their funds can be seen from the overview of the number or volume of stock trading.

There are two ways or methods used as a way to connect profit with the basis of investment, namely, return on investment and economic value added JIAFR | 55 (Ayuningrum, 2015). Economic value added is an emphasis on determining the amount of cost of capital that takes into account the cost of capital on equity. Managers in understanding financial objectives need economic value added without the need to analyze previous years.

Investors are the main actor in the movement of stock trading volume. Investors choose information that can be profitable for them in the future. In considering their investment decisions, investors do not only see one information but also look at the different types of information sources, because in one type of information source sometimes investors are not satisfied enough to make it a reason to consider their investment decisions.

Information on the ups and downs of dividend announcements can be seen as a negative or positive sign by investors and will affect the investor's desire and confidence to make stock purchases so as to increase the trading volume of stocks (Susilowati \& Sinaga, 2019). The economic value that can be measured by the cost of capital becomes one of the indicators for investors to measure and assess whether their stock investment in the company are profitable or vice versa.

Furthermore, another thing that can be seen from a company is the social program it provides to the community environment. In addition to making the community feel safe and prosperous, of course, this will have an impact on the company itself in order to survive or stand for a long period of time. If the company has done its social program to survive for a long period of time, the investors will certainly see this as a profitable thing because the company that survives for a long period of time is a company that does positive things consistently. 
Thus, some variables related to the sustainability of investments in the future become an indication to assess the movement of the capital market. If the announcement of information provided by the company shows signs or signals that are good for investors, then the volume of stock trading will rise.

Based on the description outlined above, the authors conducted a study on The Effects of Information Content of Cash Flow Statement, Dividend Payout Ratio (DPR), Economic Value Added (EVA), and Corporate Social Responsibility (CSR) on Stock Trading Volume (Empirical Study on Manufacturing Companies Listed on Indonesia Stock Exchange year 20142018).

The problem formulations in this study are: 1) Does the content of cash flow statement information affect stock trading volume? 2) Does the Dividend Payout Ratio (DPR) affect stock trading volume? 3) Does Economic Value Added (EVA) affect stock trading volume? 4) Does Corporate Social Responsibility (CSR) affect stock trading volume?

The objective of this research is to empirically test and analyze the influence of information content of cash flow statements, dividend payout ratio, economic value added and social responsibility on stock trading volume. By being able to contribute to the development of knowledge references related to trading volume and in decision making for investments, it also minimizes the risks that occur and can be additional information for the company in its performance assessment.

\section{Literature Review}

\section{Signaling Theory}

According to Sutriasih et al. (2013) and Bastomi (2014), complete, timely and accurate information is required for investors used as analysis for investment decision making. Information received by the market can be either bad news or good news. If a piece of information contains a positive value, then it is assumed that the market will have a reaction when the information is captured or received by the market. 
The effects of information content of cash flow statement, dividend payout ratio ...

\section{Agency Theory}

According to Sutriasih et al. (2013) the emergence of agency theory is due to the separation between the principal who authorizes others or managers (agents). Between the principal and the agency has a relationship that can be said to be unbalanced in information (asymmetrical information) because the agent obtains and has more information about the company compared to the principal.

\section{Cash Flow Statement}

A cash flow statement is a report that provides or presents information on cash inflows, cash outflows, and the ability of a company to obtain and generate cash obtained from operating activities, maintain operating capacity, pay dividends and meet financial obligations for a certain period (Sutriasih et al., 2013).

\section{Dividend Payout Ratio}

Dividend Payout Ratio (DPR) is a decision related to the dividend policy in which there is a comparison between dividends paid and net income earned and presented in the form of percentages. The decision concerns whether earnings are divided or paid in dividends or partially reinvested. The dividend payout ratio indicates the amount of profit to be allocated to shareholders or investors in the form of dividends (Safitri et al., 2018).

\section{Economic Value Added (EVA)}

According to Rudianto (2013) in Novalia et al. (2016), EVA is a financial management system used to see and know the company's economic profit, which states that the creation of welfare if the company can meet all capital costs and operating costs. Economic value added can help managers to better understand financial goals and thus help them to achieve goals. Economic value added does not require any comparison with the same companies in the industry and also does not make an analysis that tends years ago. This 
concept tends to emphasize determining the magnitude of the cost of capital. Taking into account the cost of capital on equity is an advantage of the economic value-added approach compared to the traditional accounting approach in measuring the performance of the investment (Ayuningrum, 2015).

\section{Corporate Social Responsibility (CSR)}

Disclosure means the presentation or release of information. Accountants pretty much use the word in a narrow sense, namely financial information submitted in an annual financial statement about a company (Vijaya, 2009). Corporate Social Responsibility is as a commitment of a company to perform and carry out its obligations based on the decision to take actions and policies with attention to the environment and stakeholders where the company conducts its activities that have a basis on the provisions of the current law (Wahyudi \& Azheri, 2008, in Ginting, 2019). Dimensions contained in CSR according to Chahal and Sharma and Russo and Tencati in Kartikasari et al. (2017), there are three dimensions namely economic dimension, the social dimension, and environment dimension.

\section{Stock Trading Volume}

Trading volume is a useful way to see the reaction or movement of the capital market to information by going through the size of the volume traded. Stock trading volume is the ratio between the number of shares traded to the number of shares that have been outstanding in a given period (Husnan, 2013 in Safitri et al., 2018). Stock trading volume is an assessment that can be influenced by many factors, such as the board of directors' policy, company performance, income level, inflation rate, demand and supply, and many other factors that affect it (Ayuningrum, 2015). Investors should consider the level of risk and profit before deciding by conducting an analysis. At the time of conducting the analysis, investors need to be published information to change their confidence which can be seen from the market reaction. In the reaction of the market, one of them is the trading volume of stocks. 
The effects of information content of cash flow statement, dividend payout ratio ...

\section{Hypothesis Development}

\section{Effect of Cash Flow Statement Information on Stock Trading Volume}

Operating activities are the main activities in generating the company's revenue. If the company's ability is higher in generating cash, it is expected JIAFR | 59 that investor confidence is also increasing that the company's operations can obtain and generate sufficient cash to maintain the company's operating capacity, pay off loans, pay or allocate dividends, and carry out new investments without relying on outside sources (Ayuningrum, 2015).

According to research by Azhar etal. (2009) on the Effect of Cash Flow Information and Accounting Profit on Stock Trading Volume in Manufacturing Companies Listed on the Indonesia Stock Exchange, operating cash flow statistically has a significant influence on stock trading volume. According to research by Hilma (2014) on the Effect of Accounting Profit and Cash Flow Information on Stock Trading Volume, operating cash flow had a significant positive effect on stock trading volume. Similar results were obtained in the study by Safitri et al. (2018) on the Influence of Cash Flow Report Information, Dividend Payout Ratio (DPR), Economic Value Added (EVA) on Stock Trading Volume. The research showed that partial operating cash flow had a significant and positive influence on stock trading volume. Based on the above researches, hypothesis developed is:

\section{$H_{1 a}:$ Operating cash flow affects stock trading volume}

Investment activity is an activity consisting of the acquisition or release of long-term assets and investments that are not equivalent to cash. This activity relates to resources whose purpose is to generate future revenues and cash flows such as the purchase of production machinery, land, and buildings (Ayuningrum, 2015). Research by Hilma (2014) shows that investment cash flow has a negative influence on stock trading volume.

However, different results were shown by Ayuningrum (2015) that investment cash flow has a significant influence on stock trading volume. Based on the above researches, hypothesis developed is: 


\section{$H_{1 b}$ : Investment cash flow affects stock trading volume}

Funding activities are activities that have an impact on changes in the amount and composition of the company's long-term debt and capital. This activity relates to how the company can obtain funds from outside parties such as the sale of shares or loans/debts if the funds from operating activities are insufficient to fund or finance the company's growth investments. It also relates to the company's ability to pay its long-term debt and dividend payments to investors from the remaining cash from its operations (Ayuningrum, 2015).

Research by Hilma (2014) shows that funding cash flow has a significant negative influence on stock trading volume. Based on the researches and description above the hypothesis developed is:

\section{$H_{1 c}$ : Operating cash flow affects stock trading volume}

\section{Effect of Dividend Payout Ratio (DPR) on Stock Trading Volume}

The dividend payout ratio is one of the indicators that can be said to be most seen by most investors to determine their decision in considering whether to invest their funds or not because the dividend payout ratio indicates the amount of profit to be allocated to shareholders in the form of dividends (Safitri et al., 2018).

Research by Ayuningrum (2015) shows that there is a significant influence between dividend payout ratio and stock trading volume. Similar results were obtained in the study by Skenda (2017) on the Effect of Economic Value Added, Current Ratio, and Dividend Payout Ratio on Trading Volume Activity with Share Price. The research shows that the variable dividend payout ratiohas a significant influence on trading volume activity. Based on the above researches, hypothesis developed is:

$\mathrm{H}_{2}$ : Dividend Payout Ratio (DPR) affects stock trading volume 
The effects of information content of cash flow statement, dividend payout ratio ...

\section{Effect of Economic Value Added (EVA) on Stock Trading Volume}

EVA (Economic Value Added) is an indicator of the company's performance that measures whether in a period the company can create added value for its capital owners (Azzahra, 2009; Ayuningrum, 2015). EVA is different from other conventional performance indicators. EVA provides parameters that are quite objective because it comes from the concept of capital costs, namely profit disputed with capital costs (Setiyantoro, 2012; Ayuningrum, 2015).

Capital costs describe the level of risk that the company has and also the expected return of investors on investments in the company. EVA considers the expectations of investors fairly and evenly through the calculation of weighted capital costs derived from the company's capital structure. EVA calculation results that show a positive value will reflect a higher return or length than the capital cost level (Ayuningrum, 2015). For large companies where authority is abundant in the management of the company between the owner (principal) and the manager (agent), EVA is easily accepted by both to reduce the agency cost in the principal-agent relationship.

When EVA is positive and increasing, it means that there has been an economic added value for the company (Azzahra, 2009; Ayuningrum, 2015). The company is said to be able to meet the expectations of investors because the return generated exceeds the level of capital costs or exceeds the expected return by the financier for his investment (Azzahra, 2009:95; Ayuningrum, 2015). This will make investors interested in investing in the company. The high interest of investors caused the demand for shares to increase so that the volume of stock trading rose. So it can be concluded that EVA influences the trading volume of stocks. Based on the above research hypothesis developed is:

$H_{3}: \quad$ Economic Value Added (EVA) affects stock trading volume 


\section{Effect of Corporate Social Responsibility (CSR) on Stock Trading Volume}

The more good news is reporting on CSR activities, the better the company's future performance prospects because the company not only JIAFR | 62 focuses on profit alone but also cares about social relations and environmental sustainability. This will be captured as a positive signal by investors because the company gets a good rating in the eyes of investors through an increase in stock demand transactions reflected in the stock trading volume.

According to research by Vijaya (2009) on the Effect of Corporate Social Responsibility Disclosure on Stock Trading Volume Activities, disclosure of social responsibility influences trading volume activity although the influence is relatively small.

Similar results were obtained in a study by Putu etal. (2017) on the Influence of Cash Flow Information, Net Income, and Corporate Social Responsibility Disclosure on Stock Trading Volume. This research shows that CSR affects stock trading volume. In addition, research by Aldorino et al. (2015) on the Influence of Corporate Social Responsibility Disclosure and Financial Performance on Stock Trading Volume in Banking and Insurance Companies in IDX also found that Corporate Social Responsibility Disclosure (CSRD) has a partial influence on stock trading volume. Based on the above researches hypothesis developed is:

\section{$H_{4:} \quad$ Corporate Social Responsibility (CSR) affects stock trading volume}

\section{Research Methods}

Sample selection was done using purposive sampling technique which is a sampling technique that is adjusted to certain criteria. Some of the criteria used in determining the sample are as follows: 1) Manufacturing companies listed on the Indonesia Stock Exchange (IDX) in 2014-2018. 2) Manufacturing companies that have published and published full annual financial statements in 2014-2018 and reported in rupiah currency. 3) Manufacturing companies that issue dividends in 2014-2018. 4) Manufacturing companies that take 
The effects of information content of cash flow statement, dividend payout ratio ...

into account annual interest expense in financial statement in 2014-2018. 5) Manufacturing companies that include social responsibility disclosures in the 2014-2018 annual report.

The type of research in this research is quantitative. There are 16 companies listed on the Jakarta Islamic Index (JII) in 2014-2018 as samples in JIAFR | 63 this study. This type of research data is secondary with data sources obtained from the official website of the Indonesia Stock Exchange (BEI), namely www.idx.co.id. In this research, multiple regression is used in hypothesis testing.

\section{Results and Discussion}

\section{Descriptive Company Statistics}

Based on table 1, the average AKO amounted to Rp 2,129,584,476,378, the lowest AKO value is - Rp 862,339,383,145, while the highest AKO value is Rp 27,692,000,000,000. Standard deviation for AKO is obtained at $4,700,486,318,600$. The average value of AKI is -Rp 1,269,655,286,206, the lowest AKI value is - Rp 29,731,000,000,000, while the highest AKI value is $R p$ 333,591,000,000. Standard deviation for AKI is obtained at $3,160,241,172,280$. The average value of AKP is -Rp. 778,936,999,818, the lowest AKP value is -Rp.13.407.000.000.000, while the highest value of AKP is Rp.5.467.570.000.000. Standard deviation for AKP obtained by $2,516,825,332,700$. The average value of the Dividend Payout Ratio (DPR) during 2014 to 2018 is 0.4339298 or $43 \%$, the lowest DPR value is 0.00031 or $0.031 \%$. While the highest DPR value is 2.24869 or $225 \%$. Standard deviation obtained by Dividend Payout Ratio (DPR) is 0.33087339 or $33 \%$. The average value of EVA in manufacturing companies during 2014 to 2018 is - $\operatorname{Rp} 57,504,034,994$. The lowest EVA value during the observation year is Rp 9,038,550,211,746, while the highest EVA value is Rp 4,949,165,093,998. The average CSR value during the observation year is 0.2699135 , the lowest CSR value is 0.02564 , while the highest CSR value is 0.76923 . Based on CSR data processing results, the deviation standard is obtained at 0.13495118 . The average value of TVA during the observation year is 0.1590439 , the 
lowest value of TVA is 0.00011 , while the highest TVA value is 1.78969 . Standard deviation obtained by TVA is 0.24858471 .

\section{Normality Test Results}

JIAFR | 64

Based on Kolmogorov-Smirnov test results on table 2, it can be seen the significance value of 0.301 . The variables in the Kolmogorov-Smirnov test have Asymp. Sig. (2-tailed) above the significant level of 0.05 means that the variables have a normal distribution, and vice versa. It shows that statistically, residual data used in regression models has a normal distribution.

Table 1. Descriptive Statistics Results

\begin{tabular}{lcrrrr}
\hline & $\mathrm{N}$ & \multicolumn{1}{c}{ Minimum } & \multicolumn{1}{c}{ Maximum } & \multicolumn{1}{c}{ Mean } & \multicolumn{1}{c}{ Std. Deviation } \\
\hline AKO & 169 & $-862,339.00$ & $27,692,000.00$ & $2,129,584.4615$ & $4,700,486.31860$ \\
AKI & 169 & $-29,731,000.00$ & $333,591.00$ & $-1,269,655.3136$ & $3,160,241.17228$ \\
AKP & 169 & $-13,407,000.00$ & $5,467,570.00$ & $-778,936.9763$ & $2,516,825.33270$ \\
DPR & 169 &, 00031 & 2,24869 &, 4339298 &, 33087339 \\
EVA & 169 & $-9,038,550.00$ & $4,949,165.00$ & $-57,504.0059$ & $1,144,458.58229$ \\
CSR & 169 &, 02564 &, 76923 &, 2699135 &, 13495118 \\
TVA & 169 &, 00011 & 1,78969 &, 1590439 &, 24858471 \\
Valid N & 169 & & & & \\
(listwise) & & & & & \\
\hline
\end{tabular}

Source: Secondary data processed, 2020

Table 2. One-Sample Kolmogorov-Smirnov Test Results

\begin{tabular}{llr}
\hline & & Unstandardized Residual \\
\hline $\mathrm{N}$ & & 169 \\
Normal Parameters & Mean &, 0000000 \\
& Std. Deviation & 1,23434635 \\
& Absolute &, 075 \\
Most Extreme Differences & Positive &, 053 \\
& Negative &,- 075 \\
Kolmogorov-Smirnov Z & &, 973 \\
Asymp. Sig. (2-tailed) & &, 301 \\
\hline a. Test distribution is Normal. & & \\
b. Calculated from data. & & \\
Source: Secondary data processed, 2020 & &
\end{tabular}


The effects of information content of cash flow statement, dividend payout ratio ...

\section{Multicollinearity Test Results}

Based on the results of multicollinearity testing on table 3 , it can be seen that each variable has a tolerance value of more than 0.1 and its VIF value does not exceed 10 . This suggests that there was no correlation between the six independent variables used in the study.

\section{Heteroscedasticity Test Results}

Based on the scatterplot graph on figure 1, it can be seen that the dots do not form a specific pattern and the data spread randomly above and below the number 0 on the Y-axis.

\section{Autocorrelation Test Results}

Based on the Durbin-Watson test results on table 4, the Durbin-Watson score can be seen as 1,876. The results showed that $\mathrm{dU}<\mathrm{DW}<4$-dU $(1,822<$ $1,876<2,178$ ), where $\mathrm{dU}$ is 1,822 while the value of 4 -dU is 2,178 . This suggests that based on Durbin-Watson testing, it can be said that there is no autocorrelation.

Table 3. Multicollinearity Test Results

\begin{tabular}{llcr}
\hline \multirow{2}{*}{ Model } & \multicolumn{2}{c}{ Collinearity Statistics } \\
& Tolerance & VIF \\
\hline (Constant) & & \\
AKO &, 808 & 1,237 \\
AKI &, 711 & 1,406 \\
AKP &, 764 & 1,308 \\
DPR &, 979 & 1,021 \\
EVA &, 802 & 1,246 \\
CSR &, 895 & 1,117 \\
\hline
\end{tabular}

a. Dependent Variable: TVA

Source: Secondary data processed, 2020 


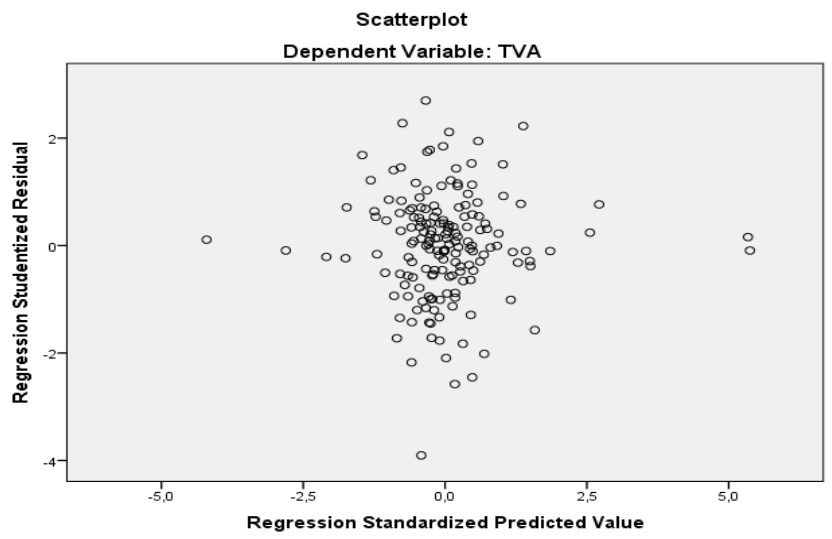

Figure 1. Heteroscedasticity Test Results

Table 4. Autocorrelation Test Results

\begin{tabular}{lrrrrr}
\hline Model & $\mathrm{R}$ & R Square & $\begin{array}{c}\text { Adjusted } \mathrm{R} \\
\text { Square }\end{array}$ & $\begin{array}{c}\text { Std. Error of the } \\
\text { Estimate }\end{array}$ & $\begin{array}{c}\text { Durbin- } \\
\text { Watson }\end{array}$ \\
\hline 1 &, $392^{\mathrm{a}}$ &, 153 &, 122 & 1,25700 & 1,876 \\
\hline
\end{tabular}

a. Predictors: (Constant), CSR, EVA, DPR, AKP, AKI, AKO

b. Dependent Variable: TVA

Source: Secondary data processed, 2020

\section{Multiple Regression Analysis Results}

Based on the results of multiple regression analysis on table 5, it can be known that the constant value (a) of the regression model used is $-11,471$ which states that if there is no independent variable then the stock trading volume is negative at $-11,471$ with the regression coefficient of each independent variable of $\mathrm{b} 1=0.015, \mathrm{~b} 2=0.847, \mathrm{~b} 3=-0.045, \mathrm{~b} 4=-0.376, \mathrm{~b} 5=$ 0.060 and $\mathrm{b} 6=-0.003$.

\section{Determination Coefficient Test Results}

When viewed from adjusted R Square value of 0.122 , it shows that AKO, AKI, AKP, DPR, EVA, and CSR are only able to explain TVA by $12.2 \%$. The remaining $87.8 \%$ was influenced by other factors not included in the regression model in this study. 
The effects of information content of cash flow statement, dividend payout ratio ...

Table 5. Multiple Regression Analysis Test Results

\begin{tabular}{rlrrrrr}
\hline & \multicolumn{1}{c}{ Unstandardized } & \multicolumn{2}{c}{$\begin{array}{c}\text { Standardized } \\
\text { Coefficients }\end{array}$} & $\begin{array}{c}\text { Coefficients } \\
\text { Beta }\end{array}$ & T & Sig. \\
& B & Std. Error & Beta & \\
\hline \multirow{4}{*}{1} & (Constant) & $-11,471$ & 4,046 & & $-2,835$ &, 005 \\
& AKO &, 015 &, 040 &, 030 &, 376 &, 707 \\
& AKI &, 847 &, 311 &, 234 & 2,725 &, 007 \\
& AKP &,- 045 &, 041 &,- 092 & $-1,115$ &, 266 \\
& DPR &,- 376 &, 110 &,- 250 & $-3,416$ &, 001 \\
& EVA &, 060 &, 041 &, 117 & 1,448 &, 149 \\
& CSR &,- 003 &, 221 &,- 001 &,- 015 &, 988 \\
\hline
\end{tabular}

a. Dependent Variable: TVA

Source: Secondary data processed, 2020

\section{Effect of Cash Flow Statement Information on Stock Trading Volume}

Based on the results of the research, a significant value of operating cash flow is 0.707 which is greater than the value of $\alpha$ worth 0.05 . The calculated $t$ value for the operating cash flow variable is 0.376 . The value is smaller than the table $t$ value of 1.975. Thus, it can be concluded that operating cash flow has no significant effect on the trading volume of shares. Based on these results, hypothesis 1a is rejected. The unproven 1a hypothesis that operating cash flow has no effect on stock trading volume indicates that companies in the manufacturing sector experience the ups and downs of net cash obtained from operating activities annually and cannot influence investors to invest in the company. This can be seen through the high low trading volume of stocks. In addition, the effect of operating cash flow on stock trading volume may be due to small cash receipts as well as from customers and others.

If the cash flow information does not show a good thing then the investor will also judge that the company cannot pay the obligations that are due and cannot pay interest or dividends. Signals contained in cash flow information are part of the company's performance or and can micro-affect stock trading volume. The company's performance results in satisfaction that comes not only from financial compensation but also from other benefits gained from 
agency relationships. These benefits can be free time, attractive conditions, flexibility of working hours, and others.

Investment cash flow has a significant value of 0.007 less than the $\alpha$ value JIAFR $\mid 68$ of 0.05 . The calculated $t$ value of 2,725 is greater than the table $t$ of 1,975 , so that the result of the data can be concluded that the investment cash flow has a significant effect on the trading volume of the shares, hence the $1 \mathrm{~b}$ hypothesis is accepted. Results that show investment cash flow has a significant effect on the trading volume of the stock means that the net cash flow of investments generated by existing companies in the manufacturing sector may reflect the level of ability of the company in a state of continued growth in the future. This gives investors a positive signal about their future guarantees. In addition, the return on investment cash flow that significantly affects the trading volume of shares shows that investors pay attention to the results of long- and short-term investments as well as the sale of fixed assets made by the company. The company's policy of making long- and short-term investments makes investors interested in buying the company's shares in the hope of making a profit.

Funding cash flow has a significant value of 0.266 . The calculated $t$ value is $-1,115$ where the figure is smaller than the table $t$ of 1,975 , so the result can be concluded that the funding cash flow has no significant effect on the trading volume of the stock. Hence, the 1c hypothesis is rejected. Results showing that funding cash flow has no significant effect on the trading volume of shares mean that funding decisions are not responded by many investors and can be said not to be the only consideration of investments so that investors pay more attention to other factors in their investment decision making. Investors argue that activities from funding cash flows such as debt issuance, loans to banks and other parties, and dividend payments are not the main considerations for making decisions in buying shares due to large payouts. 
The effects of information content of cash flow statement, dividend payout ratio ...

\section{Effect of Dividend Payout Ratio (DPR) on Stock Trading Volume}

Based on the results of the research, the significance value obtained for the variable Dividend Payout Ratio (DPR) of 0.001 is less than the value of $\alpha$ 0.05 . With a calculated $t$ value of $-3,416$ which indicates that $t$ calculates the table $(3,416>1,975)$ then the result can be concluded that the DPR has a significant effect on the trading volume of stocks so that the second hypothesis is accepted.

Results showing the DPR significantly affects the trading volume of shares indicate that investors who invest shares in companies listed in the manufacturing sector see most of these companies have a policy to distribute dividends and consider dividends as profits paid annually, and that the company can provide returns as expected, so that the DPR influences investor decisions. This indicates that investors have a goal to see and get dividends as well as get a positive signal about the stock's prospects as it indicates the company's ability to make a profit so that the trading volume of the stock increases.

According to Sutriasih et al. (2013), the announcement of accounting information, especially net profit information, will signal that the company has good prospects or potential in the future and estimate whether the company is able to generate profit in the future. Dividend announcements can signal that the market will react positively and negatively. The market will react positively in the event of a high dividend increase, because the information contained in the dividend announcement can provide a good market response so that it will have expectations for greater profits in the future and vice versa related to stock trading volume.

\section{Effect of Economic Value Added (EVA) on Stock Trading Volume}

The results of the study show the significance value of EVA is 0.149 . The value is greater than the $\alpha 0.05$ with a calculated t value of 1,448 that is less than the table $t$ value of 1,975. Based on these results, it can be concluded that 
EVA has no effect on the trading volume of shares so the third hypothesis is rejected.

The results of the study show that EVA is not the deciding factor that affects the trading volume of stocks. This is evidenced from the effect of EVA on the trading volume of stocks. EVA information is not an attraction and interest of investors in investing in stocks so the response to stock trading volume is not strong.

The results that show that EVA has no effect on the trading volume of shares can be interpreted as partly or on average the value of the company's EVA which has a negative value (EVA $<0$ ). It means that there is no valueadded process in which the company is unable to generate a rate of return on operations that exceeds the cost of capital. In other words, although the company is able to generate a high net profit, the company is experiencing a decline in value. This is one of the negative reactions of investors in making investments. Another thing can also be caused by the majority of investors in manufacturing sector companies who buy shares of a company for later resale. With the state of the majority of investors making short-term investments, the EVA which is a method that becomes the focus of long-term prosper becomes significantly ineffective. So it is not proven that EVA has information content and is not used as a consideration by investors in buying shares that affect the volume of the company's shares.

\section{Effect of Corporate Social Responsibility (CSR) on Stock Trading Volume}

The results of the research show a CSR significance value of 0.988 which is greater than the $\alpha 0.05$. The calculated $t$ value of -0.015 indicates that $t$ count $<\mathrm{t}$ table $(-0.015<1.975)$ then the result can be concluded that CSR has no significant effect on stock trading volume. So, the fourth hypothesis is rejected.

The above results showing that CSR has no significant effect on the trading volume of shares can mean that investors do not respond adequately to the social responsibility information reported in the annual report of companies listed in the manufacturing sector and do not take it into 
The effects of information content of cash flow statement, dividend payout ratio ...

consideration in making decisions. This means that investors prefer to look at other factors as their consideration to be more confident in investing in a company.

Most companies listed in the manufacturing sector disclose their social responsibilities, but the results are not influential because the average JIAFR | 71 disclosure rate is still low which is only $27 \%$ or about 21 items of 78 items that should be disclosed. Therefore, it is seen by investors not as good news information. The more good news is reporting on CSR activities, the better the company's future performance prospects because the company not only focuses on profit alone but also cares about social relations and environmental sustainability. This will be captured as a positive signal because the company gets a good rating in the eyes of investors through an increase in stock demand transactions reflected in the stock trading volume.

According to Jogiyanto (2009) in Astuti \& Widi (2015) signals in the form of CSR disclosures provided by management are very difficult to disclose economic value, so investors take longer time to react.

\section{Statistic Test Results F}

The F statistical test results show that a significant value of 0.000 is smaller than the significance level of 0.05 . The test results also show that the $F$ value is greater than the $\mathrm{F}$ table value $(4,895>2.15)$. Based on these results, it can be said that the information content of cash flow statements (operating cash flow, investment cash flow, funding cash flow), Dividend Payout Ratio, Economic Value Added and Corporate Social Responsibility simultaneously or jointly have an influence on stock trading volume.

\section{Conclusion}

Based on the results of the research that has been done, it can be concluded that operating cash flow information, funding cash flow, economic value added, and corporate social responsibility have no significant effect on the trading volume of shares of manufacturing companies. Meanwhile, 
investment cash flow information, and dividend payout ratio have significant effect on the trading volume of shares of manufacturing companies.

\section{References}

JIAFR | 72 Aldorino, C., Kharlina E. R., \& Dhia W. C. (2015). Pengaruh Corporate Social Responsibility Disclosure dan Kinerja Keuangan Terhadap Volume Perdagangan Saham pada Perusahaan Perbankan dan Asuransi di BEI, 10, 1-11.

Ayuningrum, S. (2015). Pengaruh Informasi Laporan Arus Kas, Devidend Payout Ratio (DPR), Economic Value Added (EVA) Terhadap Volume Perdagangan Saham Di Bursa Efek Indonesia. Jurnal Teknologi, 1(1), 69-73.

Azhar, A., Rofika, \& Rohayati, L. (2009). Pengaruh Informasi Arus Kas dan Laba Akuntansi terhadap Volume Perdagangan Saham pada Perusahaan Manufaktur yang Terdaftar di Bursa Efek Indonesia.

Bastomi, A. Y. Al. (2014). Pengaruh Informasi Laporan Arus Kas Terhadap Volume Perdagangan Saham pada Perusahaan Food an Beverage yang Tercatat di Bursa Efek Indonesia. Jurnal Akuntansi Unesa, 1-23.

Ginting, R. M. H. (2019). Pengaruh Corporate Social Responsibility Terhadap Nilai Perusahaan dan Volume Perdagangan, 5(1).

Hilma, M. (2014). Pengaruh Informasi Laba Akuntansi dan Arus Kas Terhadap Volume Perdagangan Saham, (September).

Kartikasari, N. D., Hidayat, K., \& Yulianto, E. (2017). Pengaruh Corporate Social Responsibility (CSR) Terhadap Citra Perusahaan Multinasional (Survei pada Konsumen Unilever di Indonesia Mengenai Program "Project Sunlight" PT Unilever Indonesia Tbk.), 43(1), 8-16.

Kurniawansyah, D., \& Kurnianto, S. (2018). Teori Agency Dalam Pemikiran Organisasi; Pendekatan Positivist Dan Principle-Agen. Jurnal Riset Akuntansi Dan Bisnis Airlangga, 3(2), 435-446.

Lie, L. (2009). Penggunaan MRA dengan Spss untuk Menguji Pengaruh Variabel Moderating terhadap Hubungan antara Variabel Independen dan Variabel Dependen. Jurnal Teknologi Informasi DINAMIK, 14(2), 90-97. 
The effects of information content of cash flow statement, dividend payout ratio ...

Maith, H. A. (2013). Analisis Laporan Keuangan Dalam Mengukur Kinerja Keuangan Pada Pt. Hanjaya Mandala Sampoerna Tbk. Jurnal Riset Ekonomi, Manajemen, Bisnis Dan Akuntansi, 1(3), 619-628.

Mulya, A. S. (n.d.). Pengungkapan Corporate Social Responsibility (CSR) Sebagai Variabel, 27-59.

Novalia, F., \& Nindito, M. (2016). Pengaruh Konservatisme Akuntansi Dan Economic Value Added Terhadap Penilaian Ekuitas Perusahaan. Jurnal Wahana Akuntansi, 11(2).

Pongoh, M. (2013). Analisis Laporan Keuangan Untuk Menilai Kinerja Keuangan Pt. Bumi Resources Tbk. Jurnal Riset Ekonomi, Manajemen, Bisnis Dan Akuntansi, 1(3), 669-679.

Prameswari Vijaya, D. (2009). Pengaruh Pengungkapan Tanggung Jawab Sosial Perusahaan Terhadap Aktivitas Volume Perdagangan dan Harga Saham, 1-24.

Purnamasari, L. (2013). Pengaruh Perubahan Dividend Payout Ratio dan Dividend Yield Terhadap Return Saham (Studi pada Perusahaan Manufaktur di Bursa Efek Indonesia), 3(2), 213-222.

Putu, N., \& Ratna Sari, M. (2017). Pengaruh Informasi Arus Kas, Laba Bersih dan Pengungkapan Corporate Social Responsibility Pada Volume Perdagangan Saham. Journal of Chemical Information and Modeling, 53(9), 1689-1699.

Rahmah, M. N., \& Komariah, E. (2016). Analisis Laporan Keuangan Dalam Menilai Kinerja Keuangan Industri Semen Yang Terdaftar Di BEI (Studi Kasus PT Indocement Tunggal Prakarsa TBK), 1(1), 43-58.

Rispayanto, S. (2013). Pengaruh Laba Kotor, Laba Operasi, Laba Bersih, dan Arus Kas Operasi Masa Mendatang (Studi Empiris Pada Perusahaan Manufaktur yang Terdaftar di BEI). Jurnal Akuntansi, 1(3), 1-29.

Safitri, R. H., Kosim, A., Nurullah, A., Indah, S., \& Andini, P. (2018). Pengaruh Informasi Laporan Arus Kas , Dividend Payout Ratio (DPR), Economic Value Added (EVA) Terhadap Volume Perdagangan Saham, 6(2), 117130.

Safkaur, O. (2015). The Analysis Impact of Agency Cost and Transaction Cost To Dividend Payout Ratio of Go Public Firms In Indonesia, 6(6), 133143. 
Sahla, W. A., \& Aliyah, S. S. R. (2016). Pengungkapan Corporate Social Responsibility Berdasarkan Global Reporting Initiative (GRI-G4) pada Perbankan Indonesia. Jurnal INTEKNA, 16(2), 101-200.

Silfi, A., Hardi, H., \& Afrinta, R. (2015). Pengaruh Laba Akuntansi, Total Arus JIAFR | 74 Kas, Komponen Arus Kas, Return On Equity terhadap Volume Perdagangan Saham pada Perusahaan Pertambangan yang Terdaftar di Bursa Efek Indonesia Tahun 2010-2013. Jurnal Online Mahasiswa Fakultas Ekonomi Universitas Riau, 2(2).

Skenda, A. G. (2017). Pengaruh Economic Value Added, Current Ratio dan Dividend Payout Ratio Terhadap Trading Volume Activity dengan Harga Saham Sebagai Variabel Moderasi.

Spence, M. (1973). Job Market Signaling. The Quarterly Journal of Economics, 87(3), 355.

Susilowati, E., \& Sinaga, H. (2019). Pengaruh Laba Bersih , Arus Kas Dan Dividen Tunai Terhadap Volume Perdagangan Saham Pada Perusahaan Publik Sektor, 4(1), 32-40.

Sutriasih, E., Gede, I., \& Gusti, I. (2013). Pengaruh Informasi Laba Bersih, Arus Kas dan Publikasi Deviden Pada Volume Perdagangan Perusahaan Manufaktur Di Bursa Efek Indonesia, 3, 1055-1070.

Toding, M. (2013). Faktor-Faktor Yang Memengaruhi Ketepatwaktuan Penyampaian Laporan Keuangan. E-Jurnal Akuntansi, 3(2), 318-333.

Widhi A. C., \& Widi Nugrahanti, Y. (2015). Pengaruh Pengungkapan Corporate Social Responsibility Terhadap Reaksi Pasar, 4(2), 90-105.

Widodo, A. W. (2016). Pengaruh Economic Value Added (EVA) Momentum, Debt Equity Ratio (DER), Net Profit Margin (NPM), Return on Asset (ROA), Return on Equity (ROE) Terhadap Kinerja Pasar. 